\title{
Ramuan Tradisional Yang Digunakan Untuk Mengatasi Demam Berdarah Di Kota Denpasar
}

\author{
Ni Putu Rela Ariani ${ }^{1}$, Putu Lakustini Cahyaningrum ${ }^{2}$, Ida Bagus Putra Suta ${ }^{3}$ \\ Prodi Kesehatan Ayurweda Fakultas Kesehatan Universitas Hindu Indonesia \\ ${ }^{1}$ niputurelaariani@gmail.com*.'2 \\ * Corresponding author
}

\begin{abstract}
Abstrak
Penyakit demam berdarah adalah penyakit menular yang disebabkan oleh virus dengue, ditularkan me-lalui perantara vektor nyamuk. Salah satu upaya untuk mengatasi demam berdarah adalah dengan mengkonsumsi ramuan tradisional. Peneltian ini bertujuan untuk mengetahui dan mendeskripsikan ramuan tradisional yang digunakan oleh masyarakat Kota Denpasar untuk mengatasi demam berdarah dengan menggunakan metode purposive sampling. Teori yang digunakan dalam kajian ini adalah teori etnomedisin dan teori fungsional struktural. Teknik pengumpulan data dengan cara observasi, wa-wancara dan studi kepustakaan secara mendalam. Sasaran penelitian ini adalah masyarakat Kota Denpasar yang pernah menggunakan ramuan tradisional untuk mengatasi demam berdarah. Berdasarkan hasil penelitian yang didapat, diketahui masyarakat Kota Denpasar menggunakan ramuan tradisional un-tuk mengatasi demam berdarah karena adanya informasi dan kepercayaan, mudah didapat, harga ter-jangkau serta sebagai pengganti obat kimia sintetis. Ramuan tradisional yang digunakan masyarakat Kota Denpasar untuk mengatasi demam berdarah adalah ramuan sari kurma dan angkak, jus jambu biji merah, rebusan angkak, loloh kunyit, loloh daun dadap, dan loloh pepaya. Tata cara penggunaan ramuan terse-but adalah dikonsumsi pada saat trombosit mengalami penurunan disesuaikan dengan kondisi pasien.
\end{abstract}

Kata Kunci : Ramuan Tradisional, Demam Berdarah, Kota Denpasar

\begin{abstract}
Dengue fever is an infectious disease caused by dengue virus, transmitted through mosquito vector intermediaries. One effort to overcome dengue fever is to consume traditional ingredients. This research aims to determine and describe the traditional ingredients used by the people of Denpasar City to over-come dengue fever by using purposive sampling method. The theory used in this study is the theory of ethnomedicin and functional structure theory. Data collection technique by means observation, inter-views and using indepth literature study. The target of this research is the people of Denpasar City who have used traditional ingredients to deal with dengue fever. Based on the results of the study, it is known that the people of Denpasar use traditional ingredients to treat dengue fever because of information and trust, are easily available, affordable prices and as a substitute for synthetic chemical drugs. Traditional ingredients used by the people of Denpasar City to deal with dengue are date palm juice and angkak ingredients, red guava juice, angkak stew, turmeric loloh, dadap leaf loloh and papaya leaf loloh. The procedure for the use of these herbs is consumed when platelets have decreased adjusted to the patient's condition.
\end{abstract}

Keywords: Traditional ingredients, dengue fever, Denpasar City 


\section{Pendahuluan}

Bali merupakan provinsi dengan destinasi wisata yang paling banyak di kunjungi oleh wisatawan. Kepadatan jumah penduduk yang bertambah setiap tahunnya dan ditambah kunjungan wisatawan yang berdatangan, mengakibatkan pengendalian pencegahan penyakit menular menjadi terganggu. Penyakit demam berdarah merupakan penyakit menular yang disebabkan oleh virus dengue, ditularkan melalui perantara vektor nyamuk dan erat kaitannya dengan perubahan iklim (Fitria, 2015:5). World Health Organization (WHO) mengatakan wabah demam berdarah sekarang telah menjadi ancaman utama bagi kesehatan masyarakat global. Pengaruh musim di Indonesia terhadap penyakit demam berdarah tidak begitu jelas, tetapi dalam garis besar dapat dikemukakan bahwa jumlah penderita meningkat antara bulan September sampai Februari yang mencapai puncaknya pada bulan Januari (Sigarlaki, 2007:148).

Masyarakat Bali percaya bahwa penyakit itu disebabkan oleh dua faktor, yaitu faktor sekala dan faktor niskala. Faktor sekala ialah penyakit yang tampak, nyata dan berwujud, misalnya luka kena pisau, pilek, memar dan sebagainya sedangkan faktor niskala ialah penyakit yang tidak tampak, tidak nyata, tanpa sebab pasti, tapi menderita sakit (Nala, 1992:3). Demam Berdarah disebabkan oleh virus dengue yang ditularkan melalui gigitan nyamuk Aedes aegypti sebagai faktor utama (Fitria, 2015:5). Sistem pembagian penyakit dalam usada juga dikelompokkan berdasarkan Ayurweda yang didasarkan atas penyebabnya, meliputi Adhyatmika adalah penyakit yang penyebabnya berasal dari dirinya sendiri seperti penyakit keturunan, penyakit kongenital dalam kandungan dan ketidakseimbangan pada unsur tri dosha. Penyebab penyakit yang kedua adalah Adhidaiwika, penyakit yang penyebabnya berasal dari pengaruh lingkungan luar, seperti pengaruh musim, gangguan niskala/supranatural (bebai, gering agung) dan pengaruh sekala dan yang ketiga adalah Adhibautika, yaitu penyakit yang disebabkan oleh benda tajam, gigitan binatang, kecelakaan sehingga menimbulkan luka. Kasus demam berdarah dalam Usada dapat digolongkan dalam Adhibautika, yang termasuk dalam bagian Wyalakrta yaitu luka akibat gigitan nyamuk. Penyakit demam berdarah juga mengalami ketidakseimbangan unsur tri dosha yaitu terjadinya peningkatan unsur pitta, ditandai dengan kenaikan suhu tubuh serta penurunan unsur kapha, yang ditandai dengan menurunnya jumlah cairan tubuh. ( Nala, 2007:5).

Upaya Pemerintah Kota Denpasar untuk menekan angka penderita demam berdarah diantaranya dengan menggalakkan program $3 \mathrm{M}$ yaitu menguras, menutup dan mengubur tempat-tempat yang bepotensi menjadi sarang nyamuk, selain itu merekrut juru pemantau jentik (jumantik), mencanangkan lomba Pemberantasan Sarang Nyamuk (PSN) dan kebersihan kota yang diselenggarakan tiap tahun dengan menyasar tiap banjar di Kota Denpasar serta program "GEMA PETIK" (Gerakan Mandiri Pemantau Jentik) yang melibatkan masyarakat. Berdasarkan upaya - upaya tersebut kasus demam berdarah masih tetap ada di Kota Denpasar (Armini, 2017,-).

Obat untuk membasmi virus dengue sampai saat ini belum ditemukan sedangkan vaksin untuk mencegahnya sangat mahal dan hanya dapat memberikan perlindungan $60 \%$ saja (Armini, 2017,-). Pengobatan konvensional pada kasus demam berdarah pada umumnya hanya diberikan pereda demam dan pemberian cairan. (Rabbaniyah, 2015:91) dalam penelitiaannya menyatakan jambu biji (Psidium guajava Linn.) dapat menghambat virus dengue dan lebih cepat menaikkan trombosit ( Muharni, 2016:57). Selain itu menurut Iryani (2016:174) menyatakan angkak (Cendawan Monascus Purpurea) dapat menaikkan trombosit karena mengandung isoflavon dan lovastatin sebagai anti inflamasi, selain itu angkak (Cendawan Monascus Purpurea) juga sebagai imunitas tubuh pada pasien demam berdarah karena mengandung lovastatin, isoflavon, rubropunktatin, dan metabolit sekunder lainnya (Prayoga, 2016:12).

Sistem pengobatan menggunakan tanaman obat sebenarnya telah digunakan semenjak jaman dahulu sebelum adanya sistem pengobatan modern, hal ini diketahui dengan adanya berbagai pengetahuan tentang lontar-lontar Usada yang berisikan berbagai cara untuk menegakkan diagnosis, terapi, pencegahan pemeliharaan dan pengobatan berbagai penyakit. Pengobatan tradisional Ayurweda menggunakan tumbuh-tumbuhan atau bagianbagiannya untuk mengatasi penyakit, bagian-bagian yang sering dipakai dalam ramuannya seperti : daun, batang, kulit pohon, akar, bunga dan buah (Vasant et al, 2007:6). Kitab suci Ayurweda merupakan bagian dari Veda Smerti yang merupakan kelompok Upaweda, oleh karena itu kitab Ayurweda disebut sebagai Ilmu Kedokteran Hindu yang dijadikan dasar dalam sistem pengobatan tradisional yang dilaksanakan khususnya di daerah Bali (Nala, 2001:23). 


\section{Metode Penelitian}

Penelitian ini dilakukan dengan menggunakan pendekatan ausadhi/ ausadha, dalam bahasa Sansekerta, ausadha merupakan tumbuhan yang dipergunakan sebagai bahan ramuan obat, bagian tumbuhan yang paling sering dipergunakan adalah akar, rimpang, tunas, batang, kulit batang, daun, bunga, buah, biji, duri, cairan, getah, minyak dan lainnya. Jenis penelitian ini adalah penelitian kualitatif.

Data dalam penelitian ini terdiri atas data kualitatif, terdiri dari data primer dan data sekunder. Data primer yang digunakan adalah hasil dari wawancara dengan beberapa orang yang pernah menggunakan ramuan tradisional untuk mengatasi demam berdarah, sedangkan data sekunder bersumber dari buku serta jurnal yang memiliki kaitan dengan penelitian. Data yang diambil dengan teknik purposive sampling dan diperoleh dengan metode observasi,wawancara dan studi kepustakaan dengan menggunakan instrument berupa catatan, recorder dan kamera untuk membantu dokumentasi penelitian. Data yang didapat kemudian di analisa dengan menggunakan metode reduksi data, penyajian data serta verifikasi data.

\section{Hasil Penelitian}

Hasil penelitian yang didapat adalah sebagai berikut : Alasan masyarakat Kota Denpasar menggunakan ramuan tradisional untuk mengatasi demam berdarah adalah karena adanya informasi dan kepercayaan, mudah didapat, harga terjangkau serta sebagai pengganti obat kimia sintetis

Berdasarkan wawancara terhadap 24 responden, ramuan tradisional yang digunakan masyarakat untuk mengatasi demam berdarah di Kota Denpasar adalah ramuan sari kurma dan angkak berjumlah 8 orang, sedangkan penggunaan sediaan bahan tunggal yang digunakan masyarakat Kota Denpasar untuk mengatasi demam berdarah adalah jus jambu biji merah (Psidium guajava Linn.) berjumlah 8 orang, menggunakan rebusan angkak (Monascus purpureus) berjumlah 3 orang, menggunakan kombinasi jus jambu biji merah (Psidium guajava Linn.), ramuan sari kurma dan angkak berjumlah dua orang, menggunakan loloh kunyit (Curcuma longa) berjumlah satu orang, menggunakan loloh daun pepaya (Carica papaya L.) sebanyak satu orang, menggunakan kombinasi loloh kunyit (Curcuma longa) dan loloh daun dadap (Erythrina variegata) berjumlah satu orang.

Tata cara masyarakat Kota Denpasar menggunakan ramuan tradisional untuk mengatasi demam berdarah adalah dengan mengkonsumsi ramuan tradisional dalam bentuk sediaan cair berupa loloh dan rebusan pada waktu trombosit mengalami penurunan dengan takaran yang disesuaikan dengan kondisi pasien.

\section{Pembahasan}

Masyarakat Kota Denpasar selain melakukan pengobatan secara konvensional, penggunaan ramuan tradisional digunakan untuk menaikkan jumlah trombosit pada kasus demam berdarah, hal ini karena belum adanya obat yang pasti untuk menyembuhkan penyakit demam berdarah. Mengacu pada teori etnomedisin yang merupakan persepsi dan konsepsi masyarakat lokal dalam memahami kesehatan atau studi yang mempelajari sistem medis etnis tradisional, penggunaan ramuan tradisional untuk mengatasi demam berdarah masih digunakan sampai sekarang (Daval, 2009:130). Kecendrungan masyarakat dalam pemilihan pengobatan tergantung pada informasi yang diperoleh masyarakat itu sendiri. Informasi yang masyarakat miliki akan membentuk suatu sikap yang akan ditunjukkan dalam tindakan pemilihan pengobatan (Indah, 2019:4).

Sehat dalam ayurweda adalah "Samadosha, samagnicha, samadhatu malakriyah, Prasannatma Indriyamanah, Swastya iti abhidiyathe" yang artinya adalah bahwa untuk mencapai sehat maka di dalam tubuh harus terjadi keseimbangan dosha, agni, dhatu dan bekerjanya sistem ekskresi (mala) dengan baik disertai perasaan bahagia yang dialami oleh atman, indria dan manah. Menurut konsep pengobatan Ayurweda dikatakan bahwa di dalam tubuh manusia terdapat tiga buah elemen yang disebut tri dosha. Ketiga elemen ini terdiri dari vayu, pitta dan kapha. Vayu yang ada di dalam tubuh manusia berupa udara, angin, bayu yang erat kaitannya dengan alat-alat tubuh yang berfungsi untuk bernafas, mengeluarkan suara, mencerna makanan, mengeluarkan kentut dan alat tubuh yang berongga. Pitta merupakan api, panas, sinar yang ada di dalam tubuh manusia, pitta inilah yang menggerakkan jantung, hati, limpa dan mata. Kapha berupa cairan, air, lendir dan larutan yang ada di dalam tubuh manusia yang erat kaitannya dengan alat-alat tubuh yang mengeluarkan air. Keseimbangan unsur tri dosha menentukan derajat kesehatan tubuh manusia, jika keseimbangan tri dosha terganggu maka terjadilah sakit (Nala, 2001:33). Ketidakseimbangan unsur tri dosha terjadi pada penyakit demam berdarah yaitu terjadinyapeningkatan unsur pitta ditandai dengan kenaikan suhu tubuh serta penurunan unsur kapha, yang ditandai dengan menurunnya jumlah cairan 
tubuh. Pengobatan dalam Ayurweda ketidakseimbangan tri dosha dapat dikembalikan ke dalam keadaan seimbang. Konsep sehat dalam Ayurweda juga dinyatakan Dirghajiwitam Sukayu Hitayu, sehat adalah bila dirinya mencapai sukhayu yaitu bahagia secara fisik dan hitayu yaitu bahagia secara sosial dialami selama umur hidupnya (dirghajiwitam). Sehat dalam Ayurweda juga dinyatakan Swasthyasya Swasthya Raksanam, Vyadhi/Duhka Parimoksanam. Ayurweda mewajibkan untuk rakshanam (memelihara) tubuh dengan baik agar selalu dalam kesadaan sehat, namun jika tubuh dalam keadaan dukha (sakit) maka wajib untuk menanggulangi atau melakukan pengobatan sampai sembuh, dari konsep ini maka seseorang akan mencapai sehat menurut Ayurweda jika seseorang mampu mempertahankan kondisi sehatnya serta berhasil menanggulangi segala macam penyakitnya menjadi sembuh kembali (Wiryanatha, 2019:4).

Penggunaan tanaman dalam ramuan obat merupakan salah satu metode pengobatan dalam usada. Sifat tanaman dalam lontar Taru Pramana adalah tis (dingin), anget (panas) dan dumelada (sedang) (Nala, 1997:2017). Setiap tanaman memiliki rasa yang berbeda, dalam Ayurweda mengenal enam rasa yang bisa dirasakan oleh lidah manusia yaitu Madhura (manis), Amla (asam), Lavana (asin), Tikta (pahit), Katu (pedas), dan Kashaya (sepet) . Keenam rasa ini disebut Sad Rasa, perpaduan rasa dalam tanaman dapat menyeimbangkan unsur Tri Dosha (Joshi, 2018).

Tanaman dalam Ayurweda dibagi menjadi 4 golongan yaitu (1) Vanaspati adalah tanaman yang menghasilkan buah, (2) Vanaspatya adalah tanaman yang menghasilkan bunga dan buah, (3) Virudh adalah tumbuhan yang batangnya menjalar, (4) Ausadhi adalah tanaman yang setelah berbuah, pohonnya mengering lalu mati. Ausadha atau bahan ramuan obat yang berasal dari tumbuh-tumbuhan, bagian yang sering dipergunakan sebagai obat adalah akar (mula), rimpang (kandha), tunas (vaya), batang (valkala), kulit batang, daun (palasa), bunga (puspa), buah (phala), biji (bija), duri (kikasa), cairan, getah, minyak dan lain-lain ( Nala, 2001:159).

Jus Jambu Biji Merah (Psidium guajava Linn.) yang digolongkan dalam kelompok tanaman vanaspatya dapat dimanfaatkan untuk menaikkan jumlah trombosit pada kasus demam berdarah karena mengandung berbagai zat yang berfungsi sebagai penghambat penyakit, salah satunya adalah jenis tanin dan flavonoidkuersetin yang dapat menghambat aktivitas enzim reverse transcriptase sehingga dapat menghambat pertumbuhan virus dengue ( Rabbaniyah, 2015:95).
Ramuan obat yang bersifat tis (dingin) salah satunya didapatkan dari sari buah-buahan yang masak. Penggunaan ramuan bahan yang bersifat tis (dingin) dapat menetralkan unsur pitta dalam tubuh (Nala, 1997:215).

Penggunaan rebusan angkak (Monascus purpureus) pada kasus demam berdarah dapat menaikkan trombosit, karena mengandung isoflavon dan lovastatin yang berperan sebagai senyawa anti inflamasi sehingga dapat mencegah terjadinya trombositopenia, salah satu penyebab terjadinya perdarahan pada kasus demam berdarah (Iryani, 2016:177). Sari Kurma digunakan dalam mengatasi demam berdarah karena mengandung unsur-unsur nutrisi mikro penyusun trombosit (asam amino dan glutathion) yang terpenuhi, sehingga proses pembentukan trombosit berjalan sangat cepat. Pada saat nafsu makan penderita demam berdarah menurun yang disebabkan rasa sakit pada daerah pencernaan, maka kurma menyediakan nutrisi yang cukup dimana $75 \%$ penyusun buah kurma terdiri dari gula (Prasetyo, 2015:60). Campuran sari kurma dan angkak pada ramuan dalam Ayurweda memiliki perpaduan rasa Kashaya, Tikta dan Madhura yang dapat menurunkan unsur pitta pada kasus demam berdarah (Joshi, 2018).

Loloh kunyit (Curcuma longa) yang digolongkan dalam kelompok tanaman ausadhi dapat dimanfaatkan sebagai antipiretik pada kasus demam berdarah karena mengandung fenol, salah satunya yaitu senyawa flavonoid. Senyawa flavonoid dalam kandungan rimpang kunyit akan menempel pada sel imun dan memberikan sinyal intraseluler untuk mengaktifkan kerja sel imun agar lebih baik (Yudiantoro, 2018:4). Dalam lontar Taru Pramana penggunaan kunyit menjadi salah satu bagian dari campuran bahan obat untuk mengatasi nyeri pada beberapa penyakit. Kunyit menpunyai khasiat tis (dingin) dapat digunakan untuk menetralkan penyakit yang bersifat panas seperti demam (Nala, 1997:241).

Penggunaan loloh daun dadap (Erythrina variegate) yang digolongkan dalam kelompok tanaman vanaspatya dapat dimanfaatkan sebagai antipiretik dan antiinflamasi pada kasus demam berdarah karena mengandung etanol, saponin, flavonoid, polifenol, tanin, dan alkaloid. Kandungan flavonoid daun dadap berperan dalam menghambat mekanisme inflamasi sehingga dapat mencegah trombositopenia penyebab terjadinya perdarahan pada kasus demam berdarah, sedangkan kandungan etanol dalam daun dadap berfungsi sebagai antipiretik dengan memblokade produksi prostaglandin yang berperan sebagai penginduksi suhu di thermostat hipotalamus yang dapat 
menurunkan demam ( Kholidha et al, 2018:282). Daun dadap memiliki rasa yang pahit, dalam lontar Taru Pramana menyatakan bahwa tanaman obat yang memiliki rasa pahit dikelompokkan dalam tanaman obat yang bekhasiat tis (dingin). Tanaman obat yang berkhasiat tis (dingin) dapat digunakan untuk menetralkan penyakit yang bersifat panas seperti demam (Nala, 1997:241).

Loloh daun pepaya (Carica papaya L.) digolongkan dalam kelompok tanaman vanaspatya memiliki rasa pahit, sehingga dalam usada digolongkan dalam tanaman yang bersifat tis (dingin) sehingga dapat dimanfaatkan untuk menurunkan demam pada kasus demam berdarah (Nala, 1997:241). Daun papaya mengandung alkaloid, flavonoid, saponin, tanin, dan glikosida berhubungan dengan aktivitas anti-inflamasi. Enzim proteinolitik seperti papain dan chymopapain dapat membantu meningkatkan jumlah trombosit, fraksi alkaloid (carpaine) terbukti bertanggung jawab atas aktivitas anti-trombositopenik serta flavonol dan flavonoid memiliki efek stimulan pada produksi sel darah. Daun pepaya juga mengandung vitamin $\mathrm{A}$, vitamin $\mathrm{B}$, vitamin $\mathrm{B} 12$, vitamin $\mathrm{C}$, vitamin $\mathrm{D}$, kalsium, magnesium, natrium, kalium, mangan dan besi . Vitamin dan mineral dapat membantu untuk meningkatkan hemoglobin, hematokrit, sel darah merah, trombosit dan protein . Vitamin A menjaga produksi empedu normal, vitamin B9 membantu dalam sintesis DNA darah, pertumbuhan sel dan pembangunan, dan vitamin B12 membantu dalam menjaga hitungan normal trombosit dan membantu untuk melawan trombositopenia . Mineral dalam daun pepaya mengatasi infeksi DENV dan ion kalsium membantu dalam proliferasi sel limfosit, memegang peran dalam agregasi platelet ketika menggabungkan dengan Vitamin D serta mencegah trombositopenia. (Agustina, 2019:38).

Tata cara masyarakat Kota Denpasar menggunakan ramuan tradisional untuk mengatasi demam berdarah adalah dengan mengkonsumsi ramuan tradisional dalam bentuk sediaan cair berupa loloh dan rebusan pada waktu trombosit mengalami penurunan dengan takaran yang disesuaikan dengan kondisi pasien. Mengacu pada teori fungsional struktural, bahan - bahan yang digunakan sebagai ramuan dalam hasil penelitian ini dibersihkan terlebih dahulu sebelum mengolahnya agar higienis, pembuatan loloh daun dadap dan loloh daun pepaya dilakukan dengan meremas-remas bahan untuk mendapatkan zat-zat yang terkandung dalam daun yang digunakan, pembuatan loloh kunyit dibuat dengan memarut kunyit untuk medapatkan sari patinya, rebusan angkak dibuat dengan merebus angkak sampai diperoleh infusa, ramuan sari kurma dan angkak diperoleh dalam kemasan yang siap untuk dikonsumsi, hal ini membuktikan bahwa tata cara penggunaan ramuan tradisional untuk mengatasi demam berdarah memiliki kejelasan dalam tata caranya dengan runtutan yang saling mendukung serta fungsinya secara jelas, sehingga penggunaan ramuan tradisional untuk mengatasi demam berdarah mempunyai fungsi manifest yaitu fungsi yang bersifat jelas dan sesuai harapan (Alwasilah, 2017:21).

\section{Simpulan dan Saran}

Berdasarkan paparan data dan pembahasan dapat disimpulkan bahwa alasan masyarakat Kota Denpasar menggunakan ramuan tradisional untuk mengatasi demam berdarah adalah karena adanya informasi dan kepercayaan, mudah didapat, harga terjangkau serta sebagai pengganti obat kimia sintetis. Ramuan tradisional yang digunakan masyarakat Kota Denpasar untuk mengatasi demam berdarah adalah ramuan Sari Kurma (Phoenix dactylifera) dan Angkak (Monascus pupureus) sedangkan sediaan bahan tunggal yang digunakan masyarakat Kota Denpasar untuk mengatasi demam berdarah adalah jus jambu biji merah (Psidium guajava Linn.), rebusan angkak (Monascus pupureus), loloh kunyit (Curcuma longa), loloh daun dadap (Erythrina variegate), loloh daun pepaya (Carica papaya L ). Tata cara masyarakat Kota Denpasar menggunakan ramuan tradisional untuk mengatasi demam berdarah adalah dengan mengkonsumsi ramuan tradisional dalam bentuk sediaan cair berupa loloh dan rebusan pada waktu trombosit mengalami penurunan dengan takaran yang disesuaikan dengan kondisi pasien.

Ada beberapa hal yang menjadi saran berkaitan dengan penelitian ini antara lain sebagai berikut : 1.Dalam rangka pelayanan kesehatan masyarakat secara komprehensif dan terintegrasi hasil penelitian ini dapat menjadi salah satu bagian tersebut.

2.Perlu adanya penelitian lanjutan guna mengetahui cara pemakaian dengan takaran yang tepat agar memberikan keyakinan dan keamanan ketika dikonsumsi oleh masyarakat.

3.Pada penelitian selanjutnya dapat dilakukan metode penelitian kuantitatif agar mendapatkan kualitas hasil penilitian yang lebih terukur.

\section{Daftar Pustaka}

Alwasilah, A. Chaedar. 2017. Pokoknya Kualitatif : Dasar-Dasar Merancang dan Melakukan 
Penelitian Kualitatif. Pustaka Jaya : Bandung

Armini Luh Putu Sri. 2017. Inovasi Pelayanan Publik

Dinas Kesehatan Kota Denpasar GEMA PETIK

( Gerakan Mandiri Pemantau

Jentik (internet) di https : // dinkes.denpasarkota.go.id

Agustina, Anniza . 2019. Pengaruh Daun Pepaya ( Carica papaya L.) Terhadap Peningkatan Trombosit Pada Pasien Demam Berdarah Dengue. Jurnal Dunia Farmasi. 4 (1) : 34-44

Daval, N. (2009). Consevation and Cultivation of

Ethnomedicinal Plants in Jharkhand. in: Trivedi,

P.C. Medicinal Plants Utilisation and

Conservation. Aavishkar Publishers Distributor, Jaipur. India, 130-136

Fitria. 2015. LC 50 Dari Ekstrak Daun Putri Malu (Mimosa pudica L.) Terhadap Larva Nyamuk Demam Berdarah ( Aedes aegypti L.) Dan Larva Nyamuk Malaria (Anopheles sp ). Stigma. 8 (1) : 5-8.
Iryani, Tesia. 2016. Manfaat Angkak Terhadap

Kenaikan Trombosit Pada Penderita $D B D$.

Majority. 5 (5) : 174-178.

Joshi, Abhishek. 2018. Materi Kuliah Tumbuhan Obat. Denpasar : UNHI

Kholidha et al. 2016. Uji Aktivitas Ekstrak Etanol Daun Dadap Serep ( Erythrina lithosperma Miq)

sebagai Antibakteri terhadap Bakteri Salmonella typhi. Jurnal Kesehatan Masyarakat. Hal. 281:290

Murhani, Septi. 2015. Efek Penggunaan Suplemen Ekstrak Daun Jambu Biji ( Psidium guajava Linn.) dan Angkak ( Monascus purpureus) Dalam Meningkatkan Trombosit Pada Demam Berdarah Dengue (DBD) di Instalasi Rawat Inap Ilmu Penyakit Dalam RSUP DR.M. Djamil Padang . Jurnal Penelitian Farmasi Indonesia. 1 (2) : 57-61.

N Nala, I Gusti Ngurah. 2001. Ayurweda Ilmu Kedokteran Hindu. Jilid I. Cetakan I Denpasar : PT. Upada Sastra. 